Public Philosophy \& Democratic Education

Volume 5 • 2016 • Issue L • pp. 29-50 • D01: 10.14746/fped.2016.5.2.20

Participatory Methods for Information Society

Www. filozofiapubliczna.amu.edu.pl • ISSN 2299-1875

들 Creative Commons BY-NC-ND 4.0

\title{
Contributing to an European vision of democratic education by engaging multiple accors in shaping ressonsible research agendas
}

\section{Nikhas Guldowsshy, Malshid Sotoudeh, Urike Bechtold, Walter Peiss}

Abstrat: Traditionally, expert-based forward looking has been applied to anticipate future challenges, solutions and strategic decisions, but limitations to this approach have become obvious - especially when considering long term perspectives - e.g. failing to include a comprehensive array of opinions. Aiming at producing sustainable strategies for responsible socio-technical change, research funding can benefit from combining forward looking and public participation to elicit socially robust knowledge from consulting with multi-actors, including citizens. In this paper, we give insights into the EU project CIMULACT - Citizen and MultiActor Consultation on Horizon 2020. In CIMULACT, more than 4500 citizens, stakeholders and experts from 30 European countries engaged online and offline to co-create research topics. These are supposed to serve as input for the next round of calls in Horizon 2020, national research agendas as well as the ninth framework programme in the making. We investigate key results of this transdisciplinary process focussing on the topic "democratic education" with regard to two levels: What issues concerning the topic were raised? Can we find a common European imaginary for "democratic education"? Our analysis shows that the results contribute to defining and describing challenges for the currently prevailing imaginary of democratic education in Europe.

\footnotetext{
* Institute of Technology Assessment, Austrian Academy of Sciences Corresponding author: niklas.gudowsky@oeaw.ac.at
} 
Keywords: public participation, transdisciplinary foresight, participatory technology assessment, research programme development, democratic education

\section{Introduction}

Current STI governance is heavily challenged to meet demands arising from complex issues such as the grand societal challenges (Boden et al., 2010; Georghiou, 2013; Kuhlmann \& Rip, 2014). A stronger orientation of research, development and innovation towards societal needs, demands and preferences has recently become a main argument under the header of RRI (Responsible Research and Innovation) in the $\mathrm{EU}^{1}$ (Owen et al., 2012).

Research programme development presents an opportunity for an early entry point of public needs and values into the innovation process (Gudowsky \& Peissl, 2016). Thus, research agendas are increasingly becoming the target of multi-actor engagement processes aiming at integrating a broader knowledge base (Könnöllä \& Haegeman, 2012; Haegemann, 2015). A vast array of engagement methods is available ${ }^{2,3}$, not only since the rise of RRI on EU scale. Designing, conducting and analysing such processes entails technology assessment, foresight as well as several other inter-disciplines which have heavily contributed to method development within the last three decades (Joss \& Bellucci, 2002; Tran \& Daim, 2008; Decker \& Ladikas 2010).

Traditionally, expert-based forward looking has been applied to anticipate future developments, challenges, solutions and strategic decisions, but limitations to this approach have become obvious - especially when considering long term perspectives - e.g. failing to include a comprehensive

1 https://ec.europa.eu/research/swafs/index.cfm?pg=policy\&lib= engagement, accessed 26.1.2016.

1 The Engage2020 Action Catalogue is an outcome of the Engage2020 project: http://actioncatalogue.eu/search, accessed 1.2.2017.

3 RRI-tools, toolkit: https://www.rri-tools.eu/search-engine\#keywords=@filterOption=40105,33847@order=@page=1, accessed 9.2.2017. 
array of opinions. Here, advice giving processes opened up to stakeholder and citizen involvement, which became a norm over the last decades. However, including laypeople (as citizens) into forward looking science, technology and innovation governance is still underexplored. Aiming at producing sustainable strategies for responsible socio-technical change, research funding can benefit from combining forward looking and public participation to elicit socially robust knowledge from consulting multi-actors, including citizens.

In this paper, we give insights into the EU project CIMULACT - Citizen and Multi-Actor Consultation on Horizon $2020^{4}$. In CIMULACT, more than 4500 citizens, stakeholders and experts from 30 European countries engaged face to face and online to co-create research topics. These are based on social needs and supposed to serve as input for the next round of calls in Horizon 2020, national research agendas as well as the ninth framework programme in the making. To illustrate both, process and outcomes, while respecting the scope of this journal, we will investigate key results of this transdisciplinary process focussing on the topic "education and democratic development of society". The topic "democratic education and education for democracy" has been selected for this contribution, since it is a key social process and topic for technology development. Here, technology is not limited to artefacts that are developed and used for a special purpose. Balabanian (2006) describes the role of social processes in technology as the binding factor of elements of technology. The idea of socio-technical systems is clearly presented in his definition: "Technology is not simply a collection of machines, but the relationships among them, and the relationships between them and people. Just as a collection of words cannot adequately represent the rich texture of language, so also a collection of machines, even interconnected machines, cannot adequately represent contemporary technology" (Balabanian, 2006).

A specific context of social processes allows to identify new actors and rules, relevant for the respective arena of technology development. Socio-technical systems include stakeholders who represent people who are involved in the

\footnotetext{
4 Website of CIMULACT: http://cimulact.eu.
} 
process and shape technology development through their interest and value-laden activities. Development of sociotechnical processes generates impulses for social development but it is embedded in the social development itself and key processes such as education (see Sotoudeh, 2009).

\section{Multi-actor engageement for ddivising STl governance}

CIMULACT is an ongoing coordination and support action (CSA) funded under Grant Agreement no. 665948 and coordinated by the Danish Board of Technology (DBT). Large parts of this project are dedicated to a multi-actor engagement process aimed at producing advisory knowledge in terms of research topics for shaping the next round of calls in the European Commission's research and development funding scheme Horizon 2020. The smaller part of this project aims at experimenting with engagement methodology, capacity building and reflecting the various methods used to draw lessons learned. The main engagement process was conducted between 2015 and 2016; the remaining time is reserved for reflection, drawing lessons learned and, finally, impact assessment (2017-2018).

Overall, the multi-actor process combines transdisciplinary long term foresight and co-creation with various analytical steps to engage citizens, stakeholders and experts in five different steps: (1) citizens visions: a collective visioning exercise, in which citizens developed desirable futures for 2050, without any constraints regarding scope and content (Jørgensen \& Schøning, 2016); (2) an analytical step, which filtered underlying and crosscutting topics ("social needs"5) from the visions; (3) co-creation: a large-scale workshop where citizens, stakeholders and experts jointly

5 In CIMULACT, the term "social need" was applied to the described cross cutting and underlying topics. However, we are aware that the distilled social needs expand the frame of what is classically described as social need in social science literature with regard to scope and level. Thus, the term "societal need" may seem more appropriate concerning the content of the found crosscutting topics. Nevertheless, in this paper we will continue to use "social need" as it reflects the official project nomenclature. CIMULACT needs found within the visions: http://www.cimulact.eu/wp-content/ 
worked on producing scenarios for "research topics" (Warnke \& Fiedler, 2016); (4) face-to-face and online consultations: enriching and prioritizing research topics in 30 national face-to-face and one online consultation (Hebáková et al., forthcoming); (5) a final policy workshop: elaborating and finalizing selected research topics with EC-policy officers and experts (Mission Publique et al., 2016).

Selecting a heterogeneous group of citizens, who are nonstakeholders but interested to discuss relevant topics is the first challenge for this participatory foresight. Citizens were invited to develop their visions which present desirable pictures of the future in a one-day visioning workshop. These citizens played an important role in the CIMULACT collective learning process. In the visioning phase citizens' views on the future in terms of hopes, well-being and fears or loss of quality of life in the long term were expressed and documented in form of visions for the next 30-40 years. With approximately 1000 citizens participating in Europe, we did not aim at gaining a representative sample. We rather aimed for high diversity by group, which means different compositions in different countries, yet being oriented by a fixed set of socio-demographic criteria (age, gender, education, occupational sector, city-country dwellers, etc.) supplemented by country specific criteria. The stakeholder involvement in the phase thereafter provided a broader group of actors access to the co-generation of knowledge. Stakeholders, experts and policy makers have been involved after the visioning phase to identify social needs which are inherent to the 179 visions which were produced across Europe, building research programme scenarios and in the face to face as well as online enrichment and validation phase (steps 3, 4, 5). Overall, more than 4500 participants engaged in the described multi-actor process.

The CIMULACT methodology is based on the CIVISTI method (Citizens visions on Science, technology and innovation), which was developed in an EU project ${ }^{6}$, led by DBT

uploads/2016/04/Cimulact_ALL_POSTER_SOCIAL_NEEDS_reduced. pdf, accessed 6.2.2017.

6 Website of the original CIVISTI project: http://www.civisti.org, accessed 6.2.2017. 
between 2008 and 2011. For a review of the original method, see Jacobi et al. (2010), Gudowsky et al. (2012), Rask (2013), Sotoudeh and Gudowsky (in this issue); for an account of its advancement and adaptation to regional and national scale see Gudowsky and Sotoudeh (forthcoming). For a theoretical placing of CIMULACT with regard to participatory foresight and STI governance as well as an analysis of the role of technology within the citizens' visions, see Gudowsky and Peissl (2016).

In this paper we will shed light on the process from citizens' visions to research topics. We will show some examples of visions, in which elements of "democratic education" popped up, will find some elements in so-called "social needs" extracted from the visions and search for relevant parts of research topics, which are fed into the political process.

\section{Visions of democratic education}

The concepts of democracy and education have been closely interlinked by thinkers discussing shaping the educational system such as Plato, Rousseau or Jefferson, yet, in the last century John Dewey was one of the first to discuss it in depth (Perry, 2009) portraying a vision of democratic education. Dewey (1916/1944) agrees with the common argument that education should support developing informed and active citizenry and furthermore states that it should promote collective sense of good, "personal initiative and adaptability" and a "personal interest in social relationships and control, and the habits of mind which secure social change without introducing disorder" (as citied in Perry ,2009). Even if later criticised (e.g. Schutz, 2001a; 2001b; Margonis, 2009), this vision remains influential today. A detailed analysis of this and later visions and their development is out of scope of this contribution. Nevertheless, it is important to emphasize that from very early stages on visions of a democratic society included a "vision of democratic education". Education as an important means for democratic development has been interpreted differently in different phases in time. For instance, in the seventeenth century, the idea of improving the knowledge of commoners and reducing the gap between 
them and aristocrats in the "Thoughts Concerning Education" published in the 1693 by the English philosopher John Locke were central. In the beginning of the $20^{\text {th }}$ century a lot of new developments with regard to schools and democracy can be observed. One of the most prominent examples is the still existing Summerhill school, which was founded 1921 in England. ${ }^{7}$ It aims for popularisation of knowledge for all children in freedom. In Austria, the former Minister for Education Otto Glöckel established the "Wiener Schulreform" (reform of the Viennese schools system, 1919-1920), an important reform in this era, aiming at preparing children at school for democratic citizenship (Wittenberg, 2002).

In the last decade, there has been a shift on European level towards competence based education, critiqued as education shifting closer to fulfil the labour markets demands (Halasz \& Michael, 2011). Biesta (2009) states, based on an analysis of UN and EU policy documents on education that the introduction of the so-called learning - economy has replaced the right to education with a duty to education and he criticises a dominant view of education under economic auspices. Also, the individual is not seen as profiteer of education but as the one who has to function according the economic requirements of the market. In the light of this shift, the quest for lifelong learning seems especially important. While in need to answer to the raised criticism towards competence based education, the corresponding EU legislation the European Reference Framework on Key Competences for Lifelong Learning - nevertheless also implemented the "ability to participate effectively and constructively in one's social and working life and engage in active and democratic participation, especially in increasingly diverse societies" as one of the eight key competences for citizens in $2006^{8}$.

In the framework of the Decade of Education for Sustainable Development ${ }^{9}$ (2005-2014) the European Democratic Education Community (EUDEC) ${ }^{10}$ was founded in 2008. It is

1 http://www.summerhillschool.co.uk, accessed 20.2.2017.

8 http://eur-lex.europa.eu/legal-content/EN/TXT/?uri=URISERV:c11090, accessed 20.2.2017.

9 http://www.desd.org/, accessed 20.2.2017.

10 http://www.eudec.org/index.html, accessed 20.2.2017. 
an European non-profit organisation that promotes democratic education as a sensible educational model for all democratic states. EUDEC considers two pillars of democratic education:

- self-determined learning,

- a learning community based on equality and mutual respect.

Such pedagogic concept requires involving individuals with the freedom and potential of critical thinking and selfdetermination. This is how Vare and Scott (2007) show the linkage between empowerment of citizens and the vision of democratic education (see also Drury et al., 2016 ${ }^{11}$ ). Drury et al. (2016) analyse the role of deliberation within contemporary high school settings and state, that deliberative abilities are crucial for students to deal with trade-offs and conflicts in a productive way. Nevertheless, deliberation defined by Chambers (2003, p. 209) as "debate and discussion aimed at producing reasonable, well-informed opinions in which participants are willing to revise preferences in light of discussion, new information, and claims made by fellow participants" (cited in Drury et al., 2016, p. 2) requires competences as well as resources. Yet, if established successfully within the educational system it can help supporting civic engagement by fostering "skills, attitudes and capacities" which help to deal with complex challenges and the acquisition of differentiated views on these.

Today, even though policy makers in democratic countries agree on the notion that education should be democratic, interpretation of the term "can vary dramatically by one's national identity and cultural traditions, ideological stance, theoretical perspective, and academic discipline" (Perry, 2009). Thus, different visions (or imaginaries) of (democratic) education arise. Applying the concept of social imaginaries to educational policy research, Rizvi (2006) states that "a social imaginary is carried in images, myths, parables, stories, legends and songs and most

" "In our analysis, we demonstrate that students with prior training in deliberation achieve higher levels of understanding trade-offs and tensions through their rhetorical behaviours of embodying a deliberative perspective, expressing inclusivity, and working through public problems." 
significantly, in the contemporary era, in the mass media" (p. 196). This is especially important when it leads to competing imaginaries, as then "people are forced to interpret and negotiate different, social imaginaries. In the public sphere, social imaginaries are thus struggled over, as different interests seek to influence perceptions through a whole range of communication and other social technologies" (Rizvi, 2006, p. 197). Therefore, imaginaries play a major role in shaping policies and as Rizvi (2006) observes, there is an ongoing struggle between "a dominant neo-liberal imaginary underpinning educational policy and [...] a democratic alternative to it".

This spikes the question what kind of imaginary of education a group of more than thousand highly heterogeneous citizens from all over Europe developed while envisioning desirable futures and if, how they depict a desirable educational concept.

\section{Democratic eductation in citienes' visions...}

In CIMULACT approximately 1000 citizens around Europe created 179 visions (desirable futures). With regard to content and context, they are highly variable and encompass a vast variety of issues. In this paper, we investigate key results of this transdisciplinary process focussing on the topic "education" with regard to two levels:

- What issues concerning the topic mentioned above were raised?

- Can we find a common European imaginary for democratic education?

Below we describe some examples from the citizens' visions and their respective connection to ideas of democratic education.

In vision 4 from Luxemburg - Technology at society's service "democracy" and "participation" are regarded as desirable conditions for society in 2050. The "human and ecological consciousness" is considered to be important for the trade-off between human "real needs" and environmental protection. In this vision, time resources play an important role in realization of a desirable future with voluntary services for the 
community. "Industrial and technological development" are regarded to be preconditions for a work-life balance. "Time dedicated to child education" and a "freely chosen contribution" to the community are regarded to be then possible as volunteer services for the community.

Individual development in the learning process is a key point in the Austrian vision four - Education means freedom. According to this vision teachers have the responsibility to adapt the learning program "to the individual learning needs and abilities of the students."

In the Belgian vision 1 - Foundations for respect, equality, diversity through education, education is considered a means to "reach an ideal of respect, an awareness to sustainable development". Democracy and interaction between diverse groups in the society play a central role in this vision. The vision includes also other elements of democratic education such as active participation. Local politicians are named as direct responsible actors for supporting the integration of citizens "leading by example".

Another important vision for "democratic education" is the Belgian Vision 2 - September 2051: back to school. This vision includes the hope of a violence free world for children. Tolerance, social integration creativity and critical thinking are considered as core values for the education of children. "No disparity between schools, schools with no social class distinction, no more apprehension about my local school, the education is everybody's job: let each pupil develop his/her critical mind, review the score system which is not always objective, boost creativity and open-mindedness". The priority has been given to real life experiences and activities that promote integration: "favour practical works to the detriment of a boring teaching, value equally culture and sport and other activities, it aims at limiting the educational disparities between different countries."

The main part of the Bulgarian vision 4-Good education - the way towards human and society development considers hopes on a new education system:

- "Free and equal access to education for everyone.

- Compulsory education up to a certain age - overcoming illiteracy.

- Interactive and distance education (using the Internet). 
- Establishment of appropriate infrastructure and encouraging children to engage in sports and arts.

- The school should provide true information about the past, in order to be an instrument of truth, not of delusion.

- More practically oriented higher education

- Schools for parents.

- Critical thinking

- Accreditation of non-formal education."

Many visions include the wish of life long learning and free access to education for all groups in the society. In addition to these important elements for democratic education, many visions formulate aims for education such as:

- Respect for other generations and nature (Vision 4 of Czech Republic Upbringing and education towards tolerance documents the hope of "a greater tolerance and decency"),

- Respect for environment resources and preparing for global collaborations and also to take part actively in public forums for citizens to influence the decisions (Ireland Vision 1 - Community Enrichment through Education),

- Respect in a well-integrated local community (Ireland Vision 1 - Community Enrichment through Education),

- Education for making people aware of more democracy in the Internet and responsibility regarding using it (Belgian Vision 4 - Citizen-centred vision),

- Learning "the common responsibility - responsibility for each other." (Belgian Vision 4 - Citizen-centred vision) (Denmark Vision $2-A$ democratic society with REAL equal opportunities),

- "Democratic Training" for learning to "participate in the democratic society" including participating in debates through social media (Denmark Vision 2 A democratic society with REAL equal opportunities),

- Education for collective responsibility, tolerance, moral obligations based economy (Ireland Vision 1 - Community Enrichment through Education).

A number of criteria for the education environment is specified in United Kingdom Vision 2 - Community Empowered Learning for the 21st Century: 
- "There is freedom of choice about whether to use the centre as it is recognised that education can now be delivered by many mechanisms, not just schools.

- Education is not age-based or results-dependent.

- Qualifications are elective.

- Access to educational resources is unlimited throughout a person's life."

The mentioned examples above can only be presented in excerpts to illustrate the richness of the visions. Overall, more than 40 of 179 CIMULACT visions include hopes, which describe parts of a vision of democratic education.

\section{... in extracted needs}

During analytical step 2 in the CIMULACT process (see above) the content of the citizens' visions was analysed by the consortium members together with ten external "challengers" from different scientific and societal domains. The participants of this synthesis workshop extracted from the 179 visions 26 underlying and cross cutting topics. These "social needs" reflect general societal issues mentioned - explicitly or implicitly - in several visions from different countries. ${ }^{12}$ The social needs were then clustered in 12 domains:

- Equality

- Unity and Cohesion

- Citizenship Awareness and Participation

- Holistic Health

- Sustainable Food

- Life Long Processes

- Strengths-Based Education and Experiential Learning

- Harmony with Nature

- Personal Developments

- Green Habitats

- Sustainable Economy

- Sustainable Energy.

12 http://www.cimulact.eu/wp-content/uploads/2016/10/CIMULACT_Deliverable-2-1-Research_programmes_scenarios-corrected. pdf, accessed 20.2.2017. 
The following excerpts of social needs touch upon topics mentioned above with regard to democratic education, including self-determined and mutual learning: ${ }^{13}$

Life-long learning (Social need 11, Social needs domain: Life Long Processes): "Life Long Learning is fundamental for: changing employment over lifetime; raising awareness about healthy living when growing older, bridging the digital divide. Then, there is a personal empowerment through education."

Enhance the quality of education (Social need 5, Social needs domain: Strengths-based education and experiential learning): “There is a need for enhancing the quality of education through: Restructuring content and learning context; personalisation starting from the student's talent, ability and learning style."

Hands-on applied learning and actionable knowledge (Social need 10, Social needs domain: Strengths-based education and experiential learning): "There is a need for experiential, practical, learning which develops personal interests and skills (including hobbies) so to unfold the children's potential."

Accessible education (Social need 8, Social needs domain: Equality): "There is a need for accessible education, which implies: - Use new technologies to offer education to everyone, all life long and to all profiles (e.g. MOOC Massive Open Online Courses); [...] High quality accessible and free education should be public; Education should take care and do not leave students behind by adapting the courses when needed; Fair territorial equity regarding education; both poor and rich areas should have the same level of quality [...]."

Personal and spiritual development (Social need 12/13, Social needs domain: Personal development): "There is a need for encouraging and enabling personal development to grow more skilled, balanced and happy individuals (and by consequence communities) through education. Therefore we need: a change in thinking and attitudes of people

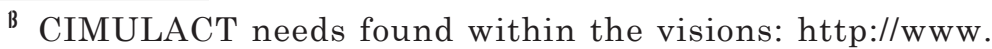
cimulact.eu/wp-content/uploads/2016/04/Cimulact_ALL_POSTER_ SOCIAL_NEEDS_reduced.pdf, accessed 6.2.2017. 
towards better life and positive world creation; society invests in the personal and spiritual development of people and thus enables people to invest in society; Learning how to listen, understand and express needs and emotions since an early age; [...] encourage personal development: critical mind, creativity, open mindedness, subject equally, valued, new infrastructures [...]."

Education by the community (Social need 6, Social needs domain: Unity and cohesion): "There is a need for an education provided by the community. Actually, members of society all encompass a lot of knowledge and wisdom and mutual learning between members of a community helps to create a common language, forms the community develops the skills and knowledge forms mutual aid. The aim is to pass knowledge about cultural traditions, content distinct traces from the community and develop new forms of it."

Education for citizenship (Social need 9, Social needs domain: Citizenship awareness and participation): "There is a need for an education that supports citizenship: this is necessary for an active society with social responsibility. This will also empower people to fulfil the role of an engaged citizen behaving responsibly as a member of the society. Additional hints: Close to 'education for green living' which can be seen as a sub need of this."

\section{... and research topiss}

During the final working conference (December 2016), consortium members, selected experts and policy officers of the European Commission prioritized 48 research programme scenarios, elaborating 23 into potential research topics, which had the greatest chance to have an impact on Horizon 2020 by the policy officers' opinion (cf. Mission Publique et al., 2016). The following section illustrates some of these elaborated topics, in particular those reflecting "democratic education". Note that CIMULACT research topics follow the official format for calls in Horizon 2020, displaying three sections: specific challenge, scope and expected impact. Most of the following citations are extracted from the "challenge" section of the respective research topic and therefore 
resemble problem descriptions, that researchers and other stakeholders are challenged with helping to solve when answering the call with their research proposals.

Evidence-based community building (Research topic 16): "Moreover, the current educational system does not foster critical and analytical thinking, so citizens have a hard time understanding evidence for the purpose of policy making. There is also the challenge of strengthening the citizens' trust in science, institutions and the policies that are meant to serve the community. In building communities, we need to empower citizens to access and consult data and evidence while accepting space for their own value based judgement" (p. 69).

Empowered Citizens (Research topic 17): "Understanding the dynamics and challenges of citizen empowerment and participation in a diverse, digital society and exploring, in empirical and/or experimental ways, how citizens could play an active part in designing, producing or running public services as well as democratic processes. The methods and tools, which are developed, should ensure that everyone (society in its diversity) has the capabilities and is motivated to take part in the process" (p.70).

Educational ecosystem as a driver of social innovation and local development (Research topic 21): "The critical and creative thinking in children is not stimulated and there is not a close enough connection to the surrounding societies. The system needs to adopt personalized approaches to empower people [...] Traditional schools should be supplemented or modified to become multi-thematic hubs, dedicated to education and collaboration among citizens of all ages. [...] promote values and foster cooperation among learning agents (schools, families, territorial stakeholders, communities, technology, environment, etc.), to satisfy individual and community needs and expectations (including personalized and practical education), promote cohesion and inclusion, and support capacity building and the increase of social capital” (p. 81).

Design thinking \& doing and life skills for all (Research topic 23): "A lack of focus on how to support self-directed and informal learning can be observed. How do we foster educating creators of 'content' and not only consumers of 'content' 
[...] foster creativity and innovation and boost learners' abilities to think 'out of the box' (set and solve the so called wicked or 'ill-defined' problems)" (p. 83). Also, expected impacts of this research topic point in the direction of democratic education: "Creative citizens (from kindergarten kids to senior citizens) who are open courageous, full of self-esteem, free from inhibitions, ready to take action responsibility. Capacity for collective action and solution finding at community level" (p. 84).

Learning for society (Research topic 23): "A more sustainable economy and ways of living, that promotes well-being, require a more balanced position between the common good and the individual good. For this shift to occur, citizens need to be educated in a life-long process, on the balance between personal fulfilment and the benefits of collective goals. Society needs to move from 'I' to 'we', building motivation and trust for change. We are too individualist, which exacerbates social problems" (p. 86).

\section{Challenges for a European imaginary of democratic education}

CIMULACT establishes and facilitates a broad and intensive dialogue between citizens, stakeholders, policy makers and experts during four years. The participatory process involves 29 consortium partners across Europe, who all do have competences and interest in organising participation but different levels of practice and experience. In itself it is an exercise in democratic education, taking a starting point at deliberating questions on desirable futures related to societal challenges. Here, the detailed working plan allowing a synthesis of theoretical and practical knowledge hence integrates creative elements for:

- societal dreaming without restrictions: getting the participants into a state of mind which detaches them of their everyday problems and duties,

- reflection of tasks for critical thinking and learning from each other,

- fair discussions in a secure climate of equality between all participants,

- selection and prioritisation mechanisms. 
One of the strengths of the CIMULACT process is giving a big picture - from visions to research topics as well as feeding national discourses by analysing the national visions in the national context as well as in comparison with European policy. The process had limited time and resources. The next step for deeper analysis of visions in the national context seems as important as the European level.

Citizens' visions in CIMULACT considering education include values of human rights, empowerment of students and self-determination and most of all the need for democracy. In addition to the mentioned examples, more than 40 of 179 CIMULACT visions include hopes, which describe parts of a vision of democratic education. Putting these criteria from different countries together makes up for a comprehensive picture of a contemporary European citizens' vision on democratic education. In short, it is about an educational system and its inherent pedagogical concepts fostering a climate to strengthen democracy by empowering individuals to actively participate in society and thereby supporting societies' transition towards a more desirable (democratic and sustainable) state.

Within the needs several of the topics raised within the visions that are concerned with education reappear, yet there is tendency in the needs to narrow the citizens' understanding and intention of education as displayed in the visions, in terms of focussing more on the individual's needs. This may be an artefact of the mode of analysis, yet it also reflects the necessity to reframe the rather holistic citizens' visions into boxes fit for further analysis and processing within CIMULACT. As we illustrated needs rather reflecting education, there are several passages in other needs focussing on participatory governance for instance.

CIMULACT contributes to what Biesta (2009, p. 154) summarises as "civic competence," which allows "for forms of civic learning that foster political agency and critical citizenship." The other - and without doubt more questionable goal of fostering civic competence could be to "domesticate' the citizen and channel his or her political agency into a very specific direction." In the light of the described shift in education policy (Biester, 2009; Halasz \& Michael, 2011), it will be interesting to follow the update of the EU key competence 
framework for life-long learning which is currently underway and scheduled to be implemented in late 2017. Will civic competences such as critical thinking and active citizenship be given more room as already elaborated by the more democratic imaginaries of democratic education, such as portrayed within the citizens' visions, or will market logics further fill the shell of the term?

Here, participatory processes such as CIMULACT are able to deliver an extended perspective which can be very valuable for problem detection and description. For instance, I'm empowered to lead my changes (Research topic 1) describes a set of challenges (European) citizens face today with regard to education and the labour market:

"Uncertainty is rising due to a rapidly changing living and working environment and there is a shift of risks and responsibilities from the state and employer to (vulnerable) individuals. Today's life-job-education pathways do not respond to the need of acquiring new skills and knowledge for having a fulfilled life. Citizens need technical, social, individual skills and an entrepreneurial mind set to stay competitive in the labour market and be able to adapt to a changing environment. They need to be able to make individual choices to cope with the quest for flexible and adaptive careers over a lifetime. There is not enough psychological knowledge on barriers for changing life jobeducation paths and for dealing effectively with uncertainty. Responsibilities of state, businesses, individuals and other actors are dissolving and new mechanisms for coping with these challenges are needed" (p.19). And they are needed to empower the individual in way that also fosters their competence to define and demand certain limits of economic reasoning over the individual (e.g. limited electronic availability, secure jobs that do not force individuals to accept an ever-rising demand for flexibility, etc.).

Yet, how these challenges will be met is unsure, and herein lies a main question for the currently predominant imaginary of democratic education in Europe: can education focussing on adaptability, flexibility and self-responsibility be considered democratic? Here, CIMULACT's main addressees - STI-policy makers - may not be the prime audience to initiate change for meeting the deeply entrenched 
needs, such as job security, or the challenges an eroding welfare state and deepening inequality are posing to citizens and society.

\section{References}

Balabanian, N. (2006). On the presumed neutrality of technology. IEEE Technology and Society Magazine, 25(4), 15-25.

Biesta, G. (2009). What Kind of Citizenship for European Higher Education? Beyond the Competent Active Citizen. European Educational Research Journal, 8(2), 146-158. doi:10.2304/ eerj.2009.8.2.146.

Boden, M., Cagnin, C., Carabias, V., Haegeman, K. and Könnölä, T. (2010). Facing the future: Time for the EU to meet global challenges, 24364 EN, 6/2010. Luxembourg: Office for Official Publications of the European Commission.

Decker, M., Ladikas, M. (Eds.) (2004). Bridges between Science, Society and Policy. Technology Assessment - Methods and Impacts. Wissenschaftsethik und Technikfolgenbeurteilung, vol. 22. Berlin-Heidelberg: Springer Verlag.

Dewey, J. (1944). Democracy and education. New York: Macmillan. (Original work published in 1916.)

Georghiou, L. (2013). Challenges for Science and Innovation Policy. In: D. Meissner, L. Gokhberg and A. Sokolov (Eds.), Science, Technology and Innovation Policy for the Future: Potentials and Limits of Foresight Studies. Berlin-Heidelberg: Springer, 233-246.

Gudowsky, N., Peissl, W. (2016). Human centred science and technology - transdisciplinary foresight and co-creation as tools for active needs-based innovation governance. European Journal of Futures Research, 4. Online first: 22.10.2016. doi:10.1007/ s40309-016-0090-4

Gudowsky, N., Sotoudeh, M. (2017). Into Blue Skies - Transdisciplinary Foresight and Co-creation as Socially Robust Tools for Visioneering Socio-technical Change. NanoEthics, 11(1), 93-106. Online first 24.2.2017. doi:10.1007/s11569-017-0284-7

Gudowsky, N., Peissl, W., Sotoudeh, M.; Bechtold, U. (2012). Forward-looking activities: incorporating citizens' visions. Poiesis \& Praxis, 9(1-2), 101-123. Online first: 15.11.2012. doi:10.1007/ s10202-012-0121-6

Haegeman, K., Spiesberger, M., Veselitskaya, N., Sokolov, A., Weiss G. (2015). FTA supporting effective priority setting in multi-lateral research programme cooperation: The case of EU-Russia S\&T cooperation. Technological Forecasting \& Social Change, 101, 200-215. 
Halász, G., Michel, A. (2011). Key Competences in Europe: interpretation, policy formulation and implementation. European Journal of Education, 46, 289-306. doi:10.1111/ j.1465-3435.2011.01491.x

Hebáková, L., Ratinger, T., Jansa L., Vančurová I. (forthcoming). CIMULACT Deliverable 4.2 European Report on Online Consultation Results.

Jacobi, A., Klüver, L., Rask, M. (2010). Relevant Research in a Knowledge Democracy: Citizens' Participation in Defining Research Agendas for Europe. In: R. J. in 't Veld (Ed.), Knowledge Democracy - Consequences for Science, Politics, and Media (pp. 87-98). Berlin-Heidelberg: Springer Verlag. doi:10.1007/978-3-642-11381-9_8

Joss, S., Bellucci, S. (2002). Participatory technology assessmentEuropean perspectives. London: University of Westminster.

Jørgensen, M. L., Schøning, S. (2015). CIMULACT Deliverable 1.3 - Vision Catalogue Encompassing the visions from all 30 countries. http://www.cimulact.eu/wp-content/uploads/2016/06/ D1.3final.pdf, accessed 20.2.2017.

Könnöllä, T., Haegeman, K. (2012) Embedding foresight in transnational research programming. Science and Public Policy, 39, 191-207. doi:10.1093/scipol/scs020

Kuhlmann, S., Rip, H. (2014). The challenge of addressing Grand Challenges. https://ec.europa.eu/research/innovation-union/pdf/ expert-groups/The_challenge_of_addressing_Grand_Challenges.pdf, accessed 6.2.2017.

Margonis, F. (2009), John Dewey's racialized visions of the student and classroom community. Educational Theory, 59, 17-39. doi:10.1111/j.1741-5446.2009.00305.x

Mission Publique, Fraunhofer Institute for Systems and Innovation Research, Strategic Design Scenarios, Politecnico di Milano $\&$ all the participants of the Pan-European Conference (2016). Deliverable 2.2 - Social needs based research programme scenarios. http://www.cimulact.eu/social-needs-based-researchprogramme-scenarios/, accessed 20.2.2017.

Owen, R., Macnaghten, P., Stilgoe, J. (2012). Responsible research and innovation: From science in society to science for society, with society. Science and Public Policy, 39, 751-760. doi:10.1093/scipol/scs093

Rask, M. (2013). The tragedy of citizen deliberation - two cases of participatory technology assessment. Technology Analysis \& Strategic Management, 25, 39-55. doi:10.1080/095373 25.2012 .751012

Perry, L. B. (2009). Conceptualizing Education Policy in Democratic Societies. Educational Policy, 23(3), 423-450. doi:10.1177/0895904807310032 
Rizvi, F. (2006). Imagination and the globalisation of educational policy research, Globalisation, Societies and Education, 4(2), 193-205. doi:10.1080/1476772060075255

Schutz, A. (2001a). John Dewey's Conundrum: Can Democratic Schools Empower? Teachers College Record, 103(2), 267-302.

Schutz, A. (2001b). "John Dewey" and "A Paradox of Size": Democratic Faith at the Limits of Experience. American Journal of Education, 109(3), 287-319. doi:10.1086/444273

Sotoudeh, M., Gudowsky, N. (forthcoming). CIVISTI - A forwardlooking method based on citizens' visions. Public Philosophy \& Democratic Education

Sotoudeh, M. (2009). Technical Education for Sustainability. An Analysis of Needs in the 21st Century. Environmental Education, Communication and Sustainability, vol. 30. Frankfurt am Main: Peter Lang Verlag.

Tran, T. A., Daim, T. (2008). A taxonomic review of methods and tools applied in technology assessment. Technological Forecasting and Social Change, 75(9), 1396-1405. doi:10.1016/j.techfore.2008.04.004

Drury, S. A. M., Andre, D., Goddard, S., Wentzel, J. (2016). Assessing Deliberative Pedagogy: Using a Learning Outcomes Rubric to Assess Tradeoffs and Tensions. Journal of Public Deliberation, 12(1). http://www.publicdeliberation.net/jpd/vol12/iss1/ art5, accessed: 20.2.2017.

Vare, P., Scott, W. (2007). Learning for a Change: exploring the relationship between education and sustainable development. Journal of Education for Sustainable Development, 1(2), 191198.

Warnke, P., Fiedler, P. (Eds.) (2016). CIMULACT Deliverable 2.1 First draft of social needs based research programme scenarios Research programme scenarios. http://www.cimulact.eu/ wp-content/uploads/2016/10/CIMULACT_Deliverable-2-1-Research_programmes_scenarios-corrected.pdf, accessed 6.2.2017.

Wittenberg, L. (2002). Geschichte der individualpsychologischen Versuchsschule in Wien. Eine Synthese aus Reformpädagogik und Individualpsychologie. Dissertation University of Vienna. Wien: WUV. 
